\title{
The Influence of Company Resources and Absorptive Capability on Value Creation and the Implication on Business Performance in the Courier Services Industry in Indonesia
}

\author{
Hana Suryana \\ Indonesia University of Education \\ hanasuryana.upi12@gmail.com
}

\begin{abstract}
The growth of business performance of courier service industry in Indonesia in the last five years are stagnant. Sales performance target is still difficult to achieve and profit growth is relatively small. This study aims to explore the data and information regarding the effect Company Resources and Absorptive Capability on Value Creation and the implication to Business Performance of courier service industry in Indonesia. The nature of this research is descriptive and verificative. The unit of analysis is the courier service industry, with a sample of 50 courier companies from various regions in Indonesia. Time horizon is cross-sectional, where the research is done at a certain time. Primary data were collected by questionnaires and interviews with customers and stakeholders. The analysis is done by using the model verification Partial Least Square (PLS). The findings reveal that Absorptive Capability (ACAP) and Company Resources) simultaneously influence Value Creation and Business Performance. Meanwhile partially, Absorptive Capability (ACAP) has a greater influence than Company Resources on Value Creation. Absorptive Capability (ACAP) has a significant influence on Business Performance, while Company Resources do not have significant influence on Business Performance. Value Creation on the other hand, has greater influence on Business Performance.
\end{abstract}

KEYWORDS: Company Resources, Absorptive Capability, Value Creation Business Performance,

\section{INTRODUCTION}

\subsection{Research Background}

Indonesia has great opportunities for logistics service providers because most business segments have shown significant revenue growth in recent years. In addition, the growth of exports of goods and services in Indonesia, which had increased approximately 9.7 to 10.8 percent in 2011, was also considered to be one of the driving factors of growth within the logistics and transportation industry in Indonesia [1]. The most needed type of logistics services is the Express and Courier Service, as many as $90 \%$ , compared to other logistics services, namely: air shipments of $60 \%, 55 \%$, transportation, shipping. by sea $55 \%$, freight forwarding $45 \%$ and warehousing and distribution as of $45 \%$ [2]. Booz \& Co [3] stated in 2009, market size of couriers was detected as much as 10, 4 trillion USD, which was participated by courier players namely Tiki by $14.4 \%$, PT Pos Indonesia by $13.5 \%, 6 \%$ by JNE and the other players take control of the rest $66.1 \%$. Thus, the competition of market share among the local, regional and even global is considerably fierce. But the growth of business performance of courier industry in the last five years tend to stagnate. The percentage of sales performance target has been still difficult to achieve, however the achievement of profit target in the last two years tend to increase, albeit relatively weak. The optimal business performance will be achieved if the company had a high growth of sales and profitability [4].

The low business performance in the courier industry, allegedly was due to the weaknesses in Value Creation. This is in effect of the products tend to not fully meet the demands of the market non-optimal creation of unique competitive product, and difficulty in creating non-imitable innovative products. The companies have not been able to establish a good cooperation with the numerous stakeholders, and also unfit to anticipate the changes in the business environment. Meanwhile, the creation of value has three important steps, which are: creating benefits for customers, having a business domain, and establishing appropriate partnerships with various stakeholders [5]

The unsolved problems stem from the management's disability in fully developing their company's Absorptive Capability [6] Tsai; Chuang; Chen described Absorptive Capability as “a firm's general ability to evaluate, assimilate, and utilize outside knowledge for commercial ends". The lack thereof is caused by the tendency of management failing to not be able to optimally take into consideration the conditions and circumstances of the company's business. Furthermore, the companies have also unable to fully consider a strategic orientation as a basis for the development of Absorptive Capability.

The courier companies have also been unable to develop their Company Resources, the resources in which the companies draw on to conduct their business activities. Their ineffectiveness is indicated by the weaknesses and insufficiencies in their tangible asset (i.e. working capital and technology). Additionally, their intangible asset, specifically in this instance, corporate reputation also faces a problem. Compared to companies abroad, their companies pale in comparison in the perception of their stakeholders. They also have a shortcoming in developing organizational capability to manage corporate culture, in which will directly influence 
business performance. According to Wheelen \& Hunger) [7], Resources are an organization's assets and are thus the basic building block of organization. They include tangible assets (i.e. plants, equipment, finances, and location); human assets (i.e. in terms of the number of employees, their skill and motivation); and intangible assets, (i.e. technological patents and copyrights, culture and reputation.)

Based on the statements above, it is important to analyze Company Resources and Absorptive Capability on Value Creation and the implication to the Business Performance in the courier services industry in Indonesia.

\subsection{Literature Review}

Company Resources are classified into three categories; physical resources, human resources, and organizational resources [8]. Wheelen and Hunger [7] stated that resources are an organization's assets and are thus the basic building blocks of the organization. They include tangible assets (i.e. plants: equipments, finances, and location); human assets (i.e. in terms of the number of employees, their skill and motivation); and intangible assets, (i.e. technological patents and copyrights, culture and reputation.)

Accoding to Tsai [6] "Absorptive Capability refers to the capability of a business to manage knowledge for customers, that is, the ability to acquire, transfer, update, renew, and apply customer knowledge. Absorptive Capability is extremely helpful for innovation [9] defined Absorptive Capability as the capability of a business to understand external information value, and to apply it for business innovation".

Weng and Huang 10] "Absorptive Capability refers to one of a firm's fundamental learning processes: its ability to identify, assimilate, and exploit knowledge from the environment [9]. Four different but complementary capabilities that compose an organizational Absorptive Capability include acquisition, assimilation, transformation, and exploitation [11].

Tsai; Chuang; Chen [12] as pointed out “ A widely accepted definition of Absorptive Capability proposed by [9] equates it with a firm's general ability to evaluate, assimilate, and utilize outside knowledge for commercial ends".

Value Creation as follow:

"to exploit a value opportunity, the company needs value-creation skills. Marketers need to: identify new customer benefits from the customer's view; utilize core competencies from its business domain; and select and manage business partners from its collaborative networks. To craft new customer benefits, marketers must understand what the customer thinks about, wants, does, and worries about. Marketers must also observe who customers admire, who they interact with and who influences them" [13]. Customer value creation focus on their customer, its core competency on business domain, and its collaborative network on business partners [14]. Business Performances are indicator of how well does organization accomplish its goals $[15,16]$ ". Hubbard \& Beamish [17], measure performance through marketing and financial performance.

\subsection{Research Objectives}

To analyze the influence of Company Resources and Absorptive Capability on Value Creation and the implication to Business Performance in the courier service industry in Indonesia.

\section{RESEARCH METHODS}

\subsection{Methods}

The method used in this paper were descriptive and explanatory survey. The objective of descriptive survey was to acquire an overview of the characteristics of each variable, while on the explanatory survey, basically was used to test the truth of a hypothesis that has been conducted through data collection in the field.

The unit of analysis were fifty courier service providers in Indonesia. Time horizon was cross-sectional, where the study was conducted at a single period of time simultaneously.

\subsection{Sample Determination Technique}

The sampling method used stratified random sampling that is a sampling method which divide the population into groups that is in this case divided by geographic area. The sample chosen is fifty courier service provider companies in some region in Indonesia.

\subsection{Hypothesis testing Design}

Due to the research objectives and the limitation of sample amount, then, analysis design use PLS (Partial least Square) that show whether the Company Resources and Absorptive Capability influences Value Creation and its implication on Business Performance in the courier service industry, can be showed from the structural model equation component or variance (PLS).

\section{DISCUSSION}

In this section, we will discuss verificative analysis through Partial Least Square (PLS). Before discussion, analysis of the two models are conducted, there are: the structural model and measurement model.

\section{A. Analysis of Measurement Model}

Measurement Model uses Second order.

All dimensions used to measure these variables has a value of loading factor greater than 0.50 , and each dimension generates Composite reliability values greater than 0.700 , so the four dimensions can be concluded as reliable.

The result of the measurement analysis showed that the most dominant dimension measured within the Company Resources variable is the "Tangible Asset" with loading factor 1,00, followed by "Intangible Asset". While in the measurement analysis of Absorptive Capability variable, the most dominant dimension measured was "Application", with loading factor 0.935 , followed by "Evaluation". Lastly, the result of Value Creation variable measurement analysis shows that the most dominant dimension was "Business partner" with loading factor 0.977 , followed by "Business domain" and "Customer Benefit". 


\section{B. Analysis of Structural Model (Inner Model)}

After the Outer Model was proven valid and reliable, the structural model was tested (Inner model). Here is the value of R-Square on the construct: Structural Model on PLS evaluated using Goodness of Fit model, which shows the difference between the observed values and the values predicted by the model.

\section{TABLE I. STRUCTURAL MODEL EVALUATION} (INNER MODEL)

\begin{tabular}{|l|l|l|l|l|l|}
\hline $\begin{array}{l}\text { Latent } \\
\text { Variabl } \\
\text { e }\end{array}$ & AVE & $\begin{array}{l}\text { Cronb } \\
\text { achs } \\
\text { Alpha }\end{array}$ & $\begin{array}{l}\text { Commun } \\
\text { ality }\end{array}$ & $\begin{array}{l}\text { R } \\
\text { Squar } \\
\text { e }\end{array}$ & $\begin{array}{l}\text { GO } \\
\text { F }\end{array}$ \\
\hline CR & 0,756 & 0,970 & 0,756 & & $\begin{array}{l}0,81 \\
4\end{array}$ \\
\hline ACAP & 0,749 & 0,943 & 0,749 & & \\
\hline VC & 0,749 & 0,984 & 0,749 & 0,884 & \\
\hline $\begin{array}{l}\text { Busines } \\
\text { S } \\
\text { Perfor } \\
\text { mance }\end{array}$ & 0,833 & 0,900 & 0,833 & 0,834 & \\
\hline
\end{tabular}

Sources: OUTPUT SmartPLS

The methods used to see the discriminant validity is the value of the square root of average variance extracted (AVE). Recommended value is above 0.5. The table above gives AVE value above 0.5 for all constructs contained in the research model.

Reliability test is reinforced by Cronbach's Alpha (suggested value is above 0.6). Reliability results will indicate if a satisfactory score above 0.7. From the table above it is known that Cronbachs Alpha for all variables> 0.7. Thereby reinforcing the test results, that the measurement model to the above variables have been consistent and accurate in measuring the construct.

Test R-squared (R2) aims to determine how well the inner workings of the model (structural model) were. According Ghozali (2011: 27),[18] the mean of $\mathrm{R}$ square value of 0.67 (good), 0.33 (moderate) and 0.19 (weak) to endogenous latent variables in the inner model. This study has a value of $\mathrm{R}$-squared of 0.916 . This result proved that this study has a good inner model, as well as GoF value of 0.916 so that it can be concluded that the model of research was supported by the empirical or model fit.

The below figure shows testing model by using Smart PLS 2.0 .

\section{Hypothesis testing}

The hypotheses tested are:

The first hypothesis is to examine the influence of Company Resources and Absorptive Capability (ACAP) on Value Creation (VC) in the courier service industry in Indonesia.
TABLE II. SIMULTANEOUS HYPOTHESIS TESTING 1

\begin{tabular}{|l|l|l|l|l|}
\hline & R2 & F & $\begin{array}{l}\text { F } \\
\text { tabel }\end{array}$ & Remark \\
\hline $\begin{array}{l}\text { CR } \\
\text { dan } \\
\begin{array}{l}\text { ACAP } \\
\text { - VC }\end{array}\end{array}$ & 0.884 & 179,086 & $3.195^{*}$ & Significant \\
\hline
\end{tabular}

The testing result shows the significant influence of Company Resources and Absorptive Capability (ACAP) simultaneously on Value Creation in the courier service industry in Indonesia ( $F$ count $>F$ table) with $R^{2}=0,884$.

\section{TABLE III. PARTIALLY HYPOTHESIS TESTING 1}

\begin{tabular}{|c|c|c|c|c|}
\hline $\begin{array}{l}\text { Inne } \\
\mathbf{r} \\
\text { Mo } \\
\text { del }\end{array}$ & $\gamma$ & $\begin{array}{l}\text { Stand } \\
\text { ard } \\
\text { Error } \\
\text { (STE } \\
\text { RR) }\end{array}$ & $\begin{array}{l}\text { T } \\
\text { Statist } \\
\text { ics } \\
(\mid \gamma \\
\text { /STER } \\
\text { R|) }\end{array}$ & Model Equation \\
\hline $\begin{array}{l}\text { CR } \\
-> \\
\text { VC }\end{array}$ & $\begin{array}{l}0,3 \\
17\end{array}$ & 0,070 & $4,533^{*}$ & $\mathrm{VC}=\mathrm{U}_{i} 317 \mathrm{CR}+\mathrm{U}_{i} 650 \mathrm{~A}$ \\
\hline $\begin{array}{l}\mathrm{AC} \\
\mathrm{AP} \text { - } \\
> \\
\mathrm{VC}\end{array}$ & $\begin{array}{l}0,6 \\
50\end{array}$ & 0,068 & 9,497* & \\
\hline
\end{tabular}

\section{Sumber: OUTPUT SmartPLS}

*Significant on $\alpha=005$

The partial testing shows that both exogenous variables significantly influence the value creation (t statistics > 2.01) in which the influence of Absorptive Capability (ACAP) is greater than Company Resources on Value Creation.

The next test is to examine whether Company Resources Absorptive Capability (ACAP) influence on Business Performance in the courier service industry in Indonesia.

TABLE IV. SIMULTANEOUS HYPOTHESIS TESTING 2

\begin{tabular}{|l|l|l|l|l|}
\hline & R2 & F & $\begin{array}{l}\text { F } \\
\text { tabel }\end{array}$ & remark \\
\hline $\begin{array}{l}\text { CR dan } \\
\text { ACAP -> } \\
\text { Business } \\
\text { Performance }\end{array}$ & 0.138 & 3.747 & $3.195^{*}$ & Significant \\
\hline
\end{tabular}

The testing shows there is a significant influence of Company Resources and Absorptive Capability (ACAP) simultaneously on Business Performance in the courier service industry in Indonesia $\left((\mathrm{F}\right.$ count $>\mathrm{F}$ table $)$ with $\mathrm{R}^{2}$ $=0,138$. 
TABLE V. PARTIAL HYPOTHESIS TESTING 2

\begin{tabular}{|c|c|c|c|c|}
\hline $\begin{array}{l}\text { Inner } \\
\text { Model }\end{array}$ & $\Gamma$ & $\begin{array}{c}\text { Standa } \\
\text { rd } \\
\text { Error } \\
\text { (STER } \\
\text { R) }\end{array}$ & $\begin{array}{c}\mathbf{T} \\
\text { Statistic } \\
\mathbf{S} \\
(\mid \gamma \\
\text { /STER } \\
\mathbf{R} \mid)\end{array}$ & Model Equation \\
\hline $\begin{array}{c}\text { CR -> } \\
\text { Business } \\
\text { Performa } \\
\text { nce }\end{array}$ & $\begin{array}{c}0,08 \\
4\end{array}$ & 0,090 & 0,934 & \multirow[t]{2}{*}{$\begin{array}{l}\text { BY }=0,084 C K \\
+0,295 \mathrm{ACAP}+\end{array}$} \\
\hline $\begin{array}{c}\text { ACAP -> } \\
\text { Business } \\
\text { Performa } \\
\text { nce }\end{array}$ & $\begin{array}{c}0,29 \\
5\end{array}$ & 0,103 & $2,850^{*}$ & \\
\hline
\end{tabular}

Sourcer: OUTPUT SmartPLS

*Significant on $\alpha=005$

Partial testing showed that only Absorptive Capability (ACAP) has a significant influence on Business Performance ( $t$ statistics > 2.01) meanwhile the influence of Company Resources is not significant on Business Performance.

The third testing is to examine the influence of Value Creation on Business Performance in the courier service industry in Indonesia

TABLE VI. PARTIAL HYPOTHESIS TESTING 3

\begin{tabular}{|l|l|l|l|l|}
\hline $\begin{array}{l}\text { Inner } \\
\text { Model }\end{array}$ & $\gamma$ & $\begin{array}{l}\text { Standa } \\
\text { rd } \\
\text { Error } \\
\text { (STER } \\
\text { R) }\end{array}$ & $\begin{array}{l}\text { T } \\
\text { Statisti } \\
\text { cs } \\
(\mid \gamma \\
\text { /STER } \\
\text { R| }\end{array}$ & Model Equation \\
\hline $\begin{array}{l}\text { VC -> } \\
\text { Business } \\
\text { Performa } \\
\text { nce }\end{array}$ & 0,55 & 0,098 & $5,676^{*}$ & BP = O,556VC + \\
\hline
\end{tabular}

Source : OUTPUT SmartPLS

*Significant on $\alpha=005$

Partial testing showed that Value Creation has a significant influence on Business Performance (t statistics > 2.01).

Conclusively, to increase business performance, the courier service industry in Indonesia have to improve its value creation. Value creation mainly formed by business partner, followed by customer benefit, and business domain. To improve Value Creation, included mainly of improving Absorptive Capability that is supported by the improvement of Company Resources. There is a significant influence of Absorptive Capability on Value Creation. It shows the need of the application of knowledge to further improve service to customers. This can be done by improving the ability of the company in the implementation of the development of knowledge-oriented and goal-oriented business processes. The application of knowledge needs to be supported with increasing knowledge evaluation. It can be done by improving the company's ability to develop employee conceptual and operational knowledge evaluation program, and then supported by improving the acquisition of knowledge, by increasing the ability of the company to enrich the knowledge that comes from internet, newspapers, magazines, and internal sources. And further supported by an improvement in the application of knowledge transfer, which can be done by increasing the ability of the company to develop education and training programs for the employee and to socialize informal knowledge.

The results of this study shows that a dominant influence of Value Creation on Business Performance, [19], is also in line with [20] [which showed that customer orientation will improve Value Creation perceived by supplier, Value Creation perceived by supplier have a mediation effect on the relationship of market orientation on Business Performance. Value Creation perceived by supplier positively related with marketing performance [21]. This study also in line with Othman \& Sheehan [22] which showed that unfit Value Creation of human resources management will lead to bad firm performance.

\section{CONCLUSION AND SUGgestion}

Company Resources and Absorptive Capability simultaneously influence Value Creation in the courier service industry in Indonesia. Partially, the influence of Absorptive Capability on Value Creation is shown to be greater, compared to Company Resources.

Company resources and Absorptive Capability simultaneously influence Business Performance of the courier service industry in Indonesia. Apparently however, only Absorptive Capability has a significant influence on Business Performance.

Value Creation has a significant influence on business in the courier service industry in Indonesia due to it being the most dominant influence on Business Performance.

The findings of this study may be used as a reference for academics to conduct future researches regarding development by using these findings as part of the premise in developing the framework. This research topic is an excellent candidate to be reviewed with the same unit of analysis but different research variables, as well as the specificity in the field of strategic management, in order to have better access to the business aspects of a more integrated manner.

\section{REFERENCE}

[1] Frost \& Sullivan, Research on Logistics, 2011.

[2] SWA Magazine, Research on Logistic Business, September 2011

[3] Booz \& Company, Fact Finding onFinal Report to PT Pos Indonesia, 2010.

[4] Wheelen, Thomas L., \& Hunger, J. David. Strategic Management And Business Policy: Concepts. $13^{\text {th }}, 2012$ Ed. Pearson/Prentice Hall

[5] Kotler, P., \& Keller, K. L.. Marketing Management . New Jersey, US: Pearson Education, 2012. 
[6] Tsai, Yi-Ching, Effect Of Social Capital And Absorptive Capability On Innovation In Internet Marketing, International Journal Of Management; Mar; 23, 1; ABI/INFORM Complete 2006 Pg. 157

[7] R Thomas L., Wheelen, \& Hunger, J. D., Strategic management and business policy: toward global sustainability. Pearson/Prentice Hall, 2012

[8] Ireland , DR, Hoskisson, RE, dan Hitt, MA, Understanding Business Strategy, 3rd edition, SouthWestern College , 2013

[9] Cohen, W. M., \& Levinthal, D. A. Absorptive capacity: A new perspective on learning and innovation. Administrative science quarterly, 1990, 128-152.

[10] Weng, Rhay-Hung; Huang, Ching-Yuan, The Impact Of Customer Knowledge Capability And Relational Capability On New Service Development Performance: The Case Of Health Service, Journal Of Management \& Organization 18(5), 2012, 608-624.

[11] Zahra, S. A., \& George, G. Absorptive capacity: A review, reconceptualization, and extension. Academy of management review, 27(2),2002, 185-203.

[12] Tsai, Ming-Tien, Phd; Chuang, Shuang Shii, Phd; Chen, Cheng-Chung, Phd, 2008, Social Interaction, Technological Capability And Innovation: An Empirical Study In The Taiwanese High-Tech Industry, The Business Review, Cambridge Vol. 11 Num. 1
[13] Kotler, Philip ; Dan Keller, Kevin Lane. 2009. Marketing Management, $13^{\text {rd }}$ Edition. New Jersey: Prentice Hall, 2009

[14] Matić, I., \& Jukić, V.,Innovativeness and Business Performances: Empirical Evidence from Bosnia and Herzegovina's Small Sized Firms. The Journal of American Academy of Business, Cambridge, 18(1), 2012, 198-205.

[15] Venkatraman, N., \& Ramanujam, V., Measurement of business performance in strategy research: A comparison of approaches. Academy of management review, 11(4), 1986, 801-814.

[16] Lin, C. Y., \& Kuo, T. H.. The mediate effect of learning and knowledge on organizational performance. Industrial Management \& Data Systems, 107(7), 2007, 1066-1083.

[17] Hubbard, Graham, And Paul Beamish, 2011, Strategic Management : Thingking, Analysis, Action, Frechs Forest, N.S.W : Pearson Australia, 2011 